\title{
The Impact of Social Media on Learning Behavior for Sustainable Education: Evidence of Students from Selected Universities in Pakistan
}

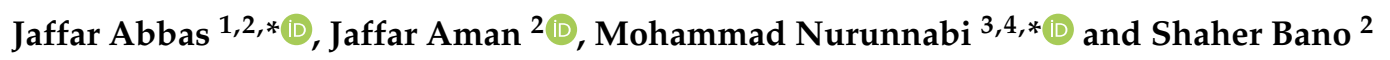 \\ 1 Antai College of Economics and Management (ACEM), School of Media and Communication (SMC), \\ Shanghai Jiao Tong University (SJTU), No. 800 Dongchuan Road, Minhang District, Shanghai 200240, China \\ 2 School of Sociology and Political Science, Shanghai University, No. 99 Shangda Road, Baoshan District, \\ Shanghai 200444, China; Jaffara@shu.edu.cn (J.A.); sbano@t.shu.edu.cn (S.B.) \\ 3 Department of Accounting, Prince Sultan University, P.O. Box 66833, Riyadh 11586, Saudi Arabia \\ 4 St Antony's College, University of Oxford, 62 Woodstock Road, Oxford OX2 6JF, UK \\ * Correspondence: abbas512@sjtu.edu.cn (J.A.); mnurunnabi@psu.edu.sa (M.N.)
}

Received: 9 February 2019; Accepted: 15 March 2019; Published: 20 March 2019

\begin{abstract}
In today's world, social media is playing an indispensable role on the learning behavior of university students to achieve sustainable education. The impact of social media on sustainable education is becoming an essential and impelling factor. The world has become a global village and technology use has made it a smaller world through social media and how it is changing instruction. This original study is amongst the few to perform a focalized investigation on revealing the relationship between positive and negative characteristics of social media and the learning attitude of university students for sustainable education. However, this study aims to examine the constructive and adverse factors that impact on students' minds and how these helped students to share positive and negative aspects with others. It is increasingly noticeable that social networking sites and their applications present enormous benefits for as well as risks to university students and their implications on students' psychological adjustment or learning behaviors are not well understood. This study adapted the cluster sampling method, and respondents participated from five selected regions. Researchers distributed 1013 questionnaires among the targeted sample of university students with an age range of 16 to 35 years, and they collected 831 complete/valid responses. This study applied the social gratification theory to examine students' behavior practicing social media usage. This study specifically identified 18 adversarial and constructive factors of social media from the previous literature. The findings revealed that the usage of social media in Pakistan has a negative influence on a student's behavior as compared to positive aspects. Results may not be generalized to the entire student community as findings are specific to the specific respondents only. This study presents a relationship between antithetical and creative characteristics of social media and exhibits avenues for future studies by facilitating a better understanding of web-based social network use.
\end{abstract}

Keywords: social media; learning attitude; sustainable education; social networking; Pakistan

\section{Introduction}

In the modern era, social media and social networks drastically influence the student community, and such technology is progressively becoming an everyday part of every individual's life in modern society [1]. Innovations are taking place rapidly in the field of information technologies and are being introduced via numerous social media and networking websites. For example, Facebook, LinkedIn, Twitter, and WhatsApp provide new-fangled social interaction patterns of communication, and some of these methods of communication are neither directed nor reciprocated [2]. Indeed, users of social 
media can read or see the online, self-published posts of their friends without direct interaction with those friends [3]. This study examines how social media and web-based interactions impact students' communities in their daily lives $[4,5]$. Thus, social media refers to computer-mediated technology facilitating the growth and sharing of ideas, awareness, career interests, information, and other methods of expression through social networks and virtual communities [6]. The contents generated by social media users, such as comments, posts, digital photos, video sharing, and all online interaction data, are critical and represent the lifeblood of social networking and social media sites [7]. Social media users typically access the services of social media via the internet or other web-based technology on their laptops or desktop computers or by downloading applications that extend the functionality of social media and social networks to mobile devices, such as smartphones or tablets [8]. As a result of engagement with such services, social media users typically create highly interactional platforms through which individual students or student organizations can share ideas, co-create, modify, and discuss user-generated content or previous content posted online. Social media directs the means of communication between students and other individuals, communities, and large organizations, and such changes are the principal focus of emerging and innovative fields of information technologies [9].

The most popular websites of social media users are Baidu, Facebook Tieba, LinkedIn, Instagram, Pinterest, Twitter, Viber, WeChat, What's App, Weibo, Wikia, and the associated messengers such as Facebook Messenger [10]. Social networking represents a social structure that displays the different settings of social actors-individuals, communities, and organizations-and encompasses the social interactions and communications of those social actors [11]. Technological innovation has resulted in both positive and negative changes in the discussion of culture and society. Ultimately, similar to any powerful platform or advancement in innovation, social media and networking sites offer both adverse and productive features to the community, and the influence of social media and social networking sites have had a significant impact on students during their transition to adulthood [12]. One of the constructive impacts of social media usage is the introduction of the public to user-generated data, ideas, and programming at a relatively young age, which has encouraged additional technological advancements and increased knowledge in student communities [13]. However, web-based social networking and the pervasiveness of social media outlets have also heightened depression in students and drastically changed the social atmosphere in which students develop and learn. This study aims to further investigate the influence of social media on students' learning and its impact on students' communities. Ultimately, this study focused on exploring the impact of technological innovation on students' learning behavior, which plays an important role in students' growth processes, and we aimed to examine various issues relating to specific examples of social media use by Pakistani students at selected universities. Web-based social networking is categorized as "gaining Internet-construct[ed] tools or applications [that are] working based on innovative and philosophical Web 2.0 establishments, and authoriz[ing] the creation and trading of consumer-produced content" [14].

This study examines the prior literature regarding social media technologies and investigates its impact on students in the Pakistani context in order to address gaps in the literature. Thus, this study aims to examine how social media relates to university students' learning behavior and its adverse and favorable consequences on psychological well-being. A thorough investigation of the prior literature related to social media technologies revealed that such research studies are either rare or non-existent. Moreover, the selected variables used in this study have not been used in prior studies. Hence, this study is the first to attempt to fill the gap in the literature on the field of social media technologies by exploring the relationship between the particular, selected variables. Therefore, this study investigates the social media usage, viewpoints, the opinion of interest, problems of media usage, and other issues of the respondents. This study illustrates the effects of increased access to information and social media on 831 respondents from different regions of Pakistan, including issues regarding the structure and usage of social networking, the reasons the respondents use social media, and how the respondents view the positive and negative aspects of social networking sites. This study is organized 
as follows. First, a literature review is presented, followed by an examination of our research methods. Then, the data and data analysis is described, including a detailed discussion of the discoveries from our investigation. Finally, our conclusions sum up the paper.

\subsection{Literature Review}

This study included a focused investigation of the prior literature of two disciplines. First, this research focused on finding the association between the productive characteristics of social media on students' communities and how social media facilitates the sharing of opinions of interest with others [15]. Second, it examined the relationship between the adverse physiognomies of social media on select Pakistani university students and the students' communities and how social media has a negative impact when students indulge in excessive use $[16,17]$. The fundamental advantage of using social media is the building of interpersonal relations through the creation of new connections. Social networks provide platforms to make friends by utilizing inconsequential interactions, communications, or participation in social groups, and enable people to socially support one another [18].

Regarding the productive aspects of social media, previous studies have focused on how social media usage is associated with social capital $[19,20]$. Thus, it refers to the "characteristics of social systems and organization, for instance, social networking, social norms, values, or social belief and trust by coordinating the cooperation to facilitate that coordination and cooperation to ensure reciprocal benefit" $[21,22]$. Communication is a way of interacting with diverse communities and individuals who are different from oneself, and it is indispensable to appreciating and comprehending various viewpoints of different kinds of people [23]. Thus, traditional societal settings, including communities, churches, schools, diverse volunteer groups, organizations, and workplaces, are crucial places for people to interact and communicate with heterogeneous individuals [24]. In the environment of digital and social media, there are more opportunities to engage with people with diverse perspectives, and such platforms offer diverse types of information sharing and means of exchanging opinions, ideas, and viewpoints with other people [25]. Several recent studies have examined how social media and other online platforms facilitate interactions and communications with different types of people-a phenomenon called network heterogeneity $[3,26]$.

\subsection{The Positive Effects of Social Media}

Social media is increasingly becoming a critical element of human society by changing our social norms, values, and culture [27,28]. Information sharing and the distribution of content are becoming important social desires [29]. Social media has changed how people, including university students-and mainly female students—communicate, interact, and socialize over the course of their learning processes at educational institutions [30]. This new form of media is playing a vital role in content sharing among universities students and the rest of society [31]. Students now have the opportunity to participate in social discussion by sharing images and pictures, posting their comments, disseminating ideas, and so on [32]. Today, social media generally impacts youths' daily lives and universities students in particular [33]. Digital media and social networking are revolutionizing methods of everyday communication, collaboration, information sharing, and information consumption $[34,35]$.

Hansen et al. (2017) defined social media as a set of online applications and tools that provide ways of social interaction and communication between digital media users by facilitating and creating knowledge sharing and ultimately transforming a monologue into a dialog, for instance, by an organization to customers [36,37]. According to various prior studies, social media includes diversified internet-based tools and applications based on a particular philosophical ideology and technological foundations and functionality [38]. Social media has changed the way its users communicate and utilize internet-based sites as a means of dispersing content among digital media and internet users [39,40]. It has created opportunities for more affordable and highly viable internet promotions of goods and services, it offers new ways to deal and coordinate interactions between potential social media 
users, and it has spurred the creation of business opportunities and system correspondence [41]. Consistently, a large number of social media users distribute their articles, photographs, videos, and recordings with the help of social media platforms, such as Facebook, WhatsApp, Viber, YouTube, Flickr, and WordPress, and they share such information with others [42].

The phenomena of user-generated data or content reached new heights in 2005 with the introduction of Web 2.0. Numerous specialists, driven by Tim O'Reilly, noted the mounting pattern of information sharing among social media users that led to the formation of the site $[37,43,44]$. Thus, Web 2.0 has turned out to be more focused on the valuable sharing of information among users. Ultimately, the best observation of the current social atmosphere refers to the relevant emerging social media of the time, for instance, Facebook (2004), Twitter (2006), and WhatsApp [45]. Several scholars have attempted to define social media, but the most adequate description and definition of social media came from Andreas Kaplan and Michael Heinlein, and they also critically distinguished the literature associated with social media.

Andreas Kaplan and Michael Heinlein depicted social media as a gathering of internet tools and applications typically based on the philosophy underlying Web 2.0 and the mechanical establishments that authorize the creation, sharing, and the trade of customer-produced content or site-generated data of social media users. Social media provides platforms that enable university students and the rest of the population to trade their ideas, thoughts, information, and conclusions; talk with each other about the substance of information; and create contacts via social networking [38]. Hence, via social media, individuals may plan content, have a sound idea involving information sharing, videos, pictures, correspondence, or coordination based on joint efforts, and create social connections with others [46]. Social media incorporates websites, wikis, video- or photo-sharing sites, and other diverse platforms. At present, participating in digital media sharing and social networking is not only beneficial, but it also facilitates individual social interactions, as well as communication, by allowing users to building brands and create professional opportunities [47]. The emerging and evolving concepts of social media tools, usage, applications, and gratification encourage us to examine the relationship between social media users and such technologies [48]. The uses and gratifications theory (UGT) refers to an approach that helps to understand the logic behind why and how individuals actively seek out specific social networking and media outlets for the satisfaction of their particular, personal goals [49]. In other words, UGT is an audience-centered method for understanding the subject of mass communication [50]. This theory deviates from other, diverse, new methods and approaches for understanding social media consequences that raise the question: what does new media do to specific individuals?

The theory of uses and gratification focuses on the actions of people and their responses to social media. Using this approach, this communication theory refers to positivism, which is based on the communication tradition of socio-psychology, and it focuses on individuals' communication at the media technologies scale. Several driving questions arise with respect to UGT: Why do people utilize mass media? What does people's usage of new media mean? Thus, this theory of UGT describes the ways in which social media users deliberately prefer media platforms that will satisfy their given desires and permit them to enhance their desired areas of interest, such as knowledge, relaxation, friendship, information sharing, ideas, social interactions, entertainment, and escape. In this sense, UGT is a human-centered approach focusing on new media, and it assumes that users have several alternatives from which to choose, allowing them to select the option that best meets their particular needs. Thus, UGT suggests that digital or social media users play an active role, and they know what alternative option to choose in order to satisfy their required needs.

\subsection{The Negative Effects of Social Media}

Recently, there has arisen a debate on the adverse impact of social media usage on people, particularly adolescents and student communities across the world. In this respect, digital media and social networking sites have received criticism, and there are many perspectives regarding the effect of social media in the context of Pakistani students. 
The popularity of social media applications and social networking sites have increased precipitously during the last decade [17]. Typically, the reason for this rapid increase is that teenagers and college and university students are using social media applications to gain global access. These social media sites, such as Facebook and Twitter, are becoming the craze in our society for everyone these days [33]. Today, students are relying increasingly on information and data that is easily accessible on social networking sites and the internet [51]. This is the reason why students' learning skills and research capabilities are decreasing in certain situations, as their engagement with these sites reduces their focus, which causes them to dedicate less time to their studies and results in a decline in their academic performance [52]. Typically, as students spend more time on social media, they spend less time socializing face to face or in person with other people, and these habits reduce their communication skills [53]. The wasting of students' time on social media may also cause them to miss deadlines on occasion [54]. As a result, students might not be able to communicate and socialize effectively in person, and it is well known that strong communication skills are a key to success [53]. Moreover, excessive social media use affects students' mental and physical health [55]. Students delay their meals and fail to rest properly; instead, they consume excessive amounts of tea or coffee to remain alert and active. This lifestyle has adverse effects on students' mental and physical health. Additionally, the daily overuse of social media is unhealthy, because it enables students to avoid creating face-to-face bonds with people [56]. Parents are responsible for monitoring their children's use of social media, and they should be vigilant about whether their children use the internet for an appropriate amount of time. Ultimately, educators and peers are also responsible for helping students understand the adverse effects of social media on health, and they should make students aware of what they can lose in the real world when they spend excessive amounts of time on social media sites [57].

The adverse effects of these social networking sites outweigh the positive ones. Thus, these sites have caused potential harm to society. Students become victims of social networks more often than anyone else. This may be because social media is an attractive way for students to avoid boredom while they are studying or searching their course material online, diverting their attention from their work [58]. Social media platforms have also been criticized for revealing and fueling negativity, which has a net-negative effect on students. For instance, the following social media platforms have been ranked from the most to the least negative based on user evaluations: Twitter, Facebook, Snapchat, and Instagram. Users have described Instagram, in particular, as having a negative effect on people by causing stress and tension on individuals' bodies. According to Steven Strogatz of Cornell University, online networking can make it more difficult for people to identify meaningful communication from other diverse interactions or connections created via web-based social networks [59]. Such a reduction in the number of significant connections may intimidate individuals, making them fear the development of important interactions and communication. Online networks also affect adolescents' and individuals' health when they excessive use of social media $[55,60]$.

Figure 1: Conceptual Framework. 


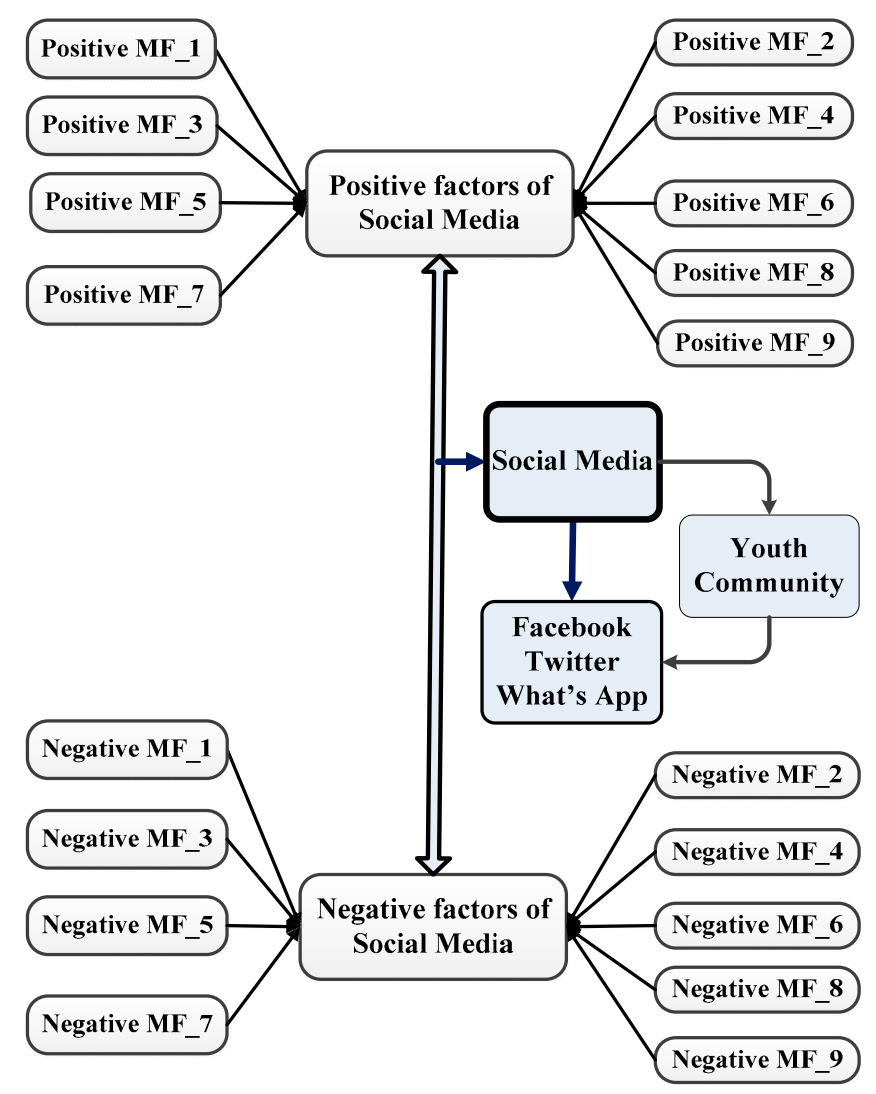

Figure 1. Chart displaying positive media factors (PMF) and negative media factors (NMF) [61-64].

Social media usage is a useful tool for improving the social capital of citizens, as it can strengthen existing social relationships, help them to stay connected and to keep in touch, stay well inform them about longstanding connections and activities, and create new contacts [65]. As the youths of this generation are growing up, they are actively making good relationships with different types of people through social networks [66]. Thus, social networks have both positive and adverse effects on students and other young people, and the ultimate effect on a student depends on his/her behavior. The positive impact of social media includes several aspects, such as social interaction, staying connected with friends, exchanging useful information with others through social networking sites, and access to sites that allow students to find online support that may be missing in traditional relationships $[60,64]$. During this phase of critical development in their lives and careers, students also turn to social networking sites for advice and new information on how to satisfy their professional goals.

In the literature, several scholars have investigated the topic of social media, and many theories and research models have been developed to describe social networking and students' behaviors, but the most prominent theories supporting such studies of social media include the theory of personal behavior, the theory of social behavior, and communication theory. This study considered three communication theories: the theory of the magic bullet, the theory of uses and gratification, and the theory of technological determinism, respectively [67]. Prolonged sitting is considered to be one of the most dangerous factors affecting human health, making adolescents, in particular, more susceptible to various diseases, because they sit for extended hours using social networking sites, and the pervasiveness of the negative impact of prolonged sitting is growing every year. Many health concerns are associated with actions that people typically perform while sitting and focusing on social networking sites or other smart devices, and many people neglect to heed information regarding such issues. Similarly, people demand scientific facts for why social media negatively impacts health, and because it has not been proven to have any relation to brain science as research is ongoing, people are not convinced. The American Academy of Pediatrics has already cautioned the public 
about the probable negative impacts of online networking and social media usage in adolescents and youths, because some young people have been shown to use social media for negative purposes, such as digital tormenting and excessive use of social media has also led to the phenomenon of "Facebook despondency". Thus, parallel dangers might affect the health of adults, transcending age. There has been some research demonstrating that web-based social networking and online media use are harmful to mental prosperity and that, in some ways, it can be harming to one's overall health. Several scholars and specialists have mentioned that online networking may affect health, and they advise people to aim for a balanced use of social media [68]. A survey conducted by Nottingham Trent University explored the intersection of mental abilities, personal identity, and online social networking use. The authors presumed that it is possible to have a dialogue about social media use, particularly "Facebook Addiction Disorder". Regardless of personal lifestyle, idealism, mental distraction, the inclination of changing resilience, personal encounters, and disguising addictive behavior towards technology, the group of people who suffer from such an addiction utilize social networks excessively. The survey interestingly found that the reasons people are inspired to overutilize friendly communities vary based upon the specific qualities of the person in question, because such individuals often have narcissistic characteristics [69].

Another undesirable effect of social networks is that people can became dependent on it, and when people spend a lot of time on social media, it can diminish their focus and attention on a specific job. Social networks can also directly influence children when people share photos and videos on that depict violence and shocking images that can disturb the behavior of children or adolescents. Social networks may even cause larger societal harm by attacking people's privacy. Social ties also affect family life, and such ties are weakened when people spend more time on social networking sites interacting with online friends. Furthermore, people who share their photos, videos, and other information on social networks may have a difficult time preventing others from reusing such content in an undesirable way [70]. Some scholars have described the structure that new media sites should follow, and they have discovered resemblances between social networks, individuals and community observations, and belief. The study of theories on this topic attempts to regulate the association between students' communities and their day-to-day use of the internet and collaborative media to highlight strategies for managing future use based on people's experiences $[4,19]$. Table 1 presents theories that could be favorable for future social media studies below.

Table 1. Various theories supporting social media impact.

\begin{tabular}{cc}
\hline The Theories on Personal Behavior & \\
\hline Theories and Models & References \\
\hline The Attribution Theory & {$[71,72]$} \\
The Model Elaboration Likelihood & {$[73]$} \\
Theory of Existence, Relatedness, and Growth & {$[74,75]$} \\
The Model: Expectation and Disconfirmation & {$[76,77]$} \\
The Behavior Model, Goal-directed & {$[78]$} \\
Theory of cultural differences by Hofstede & {$[79]$} \\
Personality Traits & {$[58]$} \\
Psychological Choice Model & {$[80,81]$} \\
Risk Perception Theory & {$[82,83]$} \\
\hline Theories: Supporting Mass Communication & \\
\hline Theories and Models & References \\
\hline Theory of Media Richness & {$[84,85]$} \\
Theory of Para-social Interaction Colliander and Dahlén $(2011)$ & {$[86]$} \\
Theory of Uses and Gratifications & {$[49,87]$} \\
\hline
\end{tabular}


Table 1. Cont.

\begin{tabular}{cc}
\hline Supporting Social Media, Social Behavior Theories & \\
\hline Theories and Models & References \\
\hline The Cognitive Map & {$[88]$} \\
The Process of Effectuation & {$[89,90]$} \\
Theory of Involvement & {$[91,92]$} \\
Theory of Justice & {$[93,94]$} \\
Theory of Social Exchange & {$[95,96]$} \\
Theory of Social Influence & {$[97,98]$} \\
Theories of Social Network Analysis & {$[99,100]$} \\
\hline
\end{tabular}

\section{Materials and Methods}

\subsection{Research Methodology}

This study analyzed the prior literature to explore the constructive and negative factors or elements of social media that typically impact students' learning behavior. Therefore, to develop a comprehensive understanding of this topic, we performed an exhaustive examination of the prior literature found within quality journals and books. This study also examined postulations, meeting procedures, and periodicals to identify supplementary information addressing the factors related to the subject of this study. Thus, our research resulted in the identification of 18 of the most critical elements of social media impacting students today. Furthermore, we developed a survey to understand the view of the student community regarding social networking sites. Before administering the survey, we consulted 16 specialists to ensure that the survey is adequate and suitable. We adjusted the study design per their expert opinions before administering the survey, including proper variables in the study and excluding some traditional or irrelevant elements. This study has adopted a mixed method (survey and interviews) of sampling, and a probability cluster sampling method was used in the data collection. Cluster sampling or one-stage cluster sampling is a method that uses clusters of respondents to represent the wider population of the targeted sample [101]. The primary purpose of cluster sampling is the representation of all groups of respondents in a specific study [102]. This study collected data from the selected areas from July to September 2018. The respondents were solicited to complete the questionnaire by utilizing a Likert scale. The survey consisted of two classifications of selected elements, including the positive factors and negative factors of social media use. We recorded the responses of the respondents considering the selected variables and the information accumulated via a poll review, and the collected data was broken down using Statistical Package SPSS 25.

Statistical package SPSS 25 was utilized to check the dependability of the gathered data. At this point, the standard deviation (SD) and mean score (M) for each characteristic were calculated, identifying the most impactful factors. Next, we applied a $t$-test and analysis of variance (ANOVA) to assess and verify the consistency of the respondents' opinions. In summary, the discoveries of the investigation identified significant information that could be used to assess the essential elements affecting students' learning behavior. Then, 16 media specialists involved in the survey provided their input for the poll study by examining the survey discoveries and data, and the experts recommended practical proposals based on the findings of the study. The primary objective of this study was to discover the positive and negative factors of social media and how these factors affect the behavior of the student community in the context of Pakistan. After careful examination and screening, this study incorporated 18 factors that were found to influence student behavior, and we developed a survey that included these elements to collect responses assessing the relative significance of the selected items.

\subsection{Influencing Factors List}

The critical challenge of this study was to explore effect of the social media impacts identified in the prior literature on the student community in Pakistan. Hence, the study explicitly focused on 
earlier research to determine the positive and negative elements of social media that characteristically influence students and other groups of society. These critical social media factors were identified during a pilot survey and classified into two sets, namely, positive and negative factors. The Table 2 below displays these factors as follows.

Table 2. Positive and Negative Factors.

\begin{tabular}{ccc}
\hline Sr. \# & Influencing Factors & References Source \\
\hline 1 & Positive Factors & \\
2 & Creates awareness & {$[20]$} \\
3 & Lecture sharing & {$[103]$} \\
4 & Easy communication & {$[19,104]$} \\
5 & Helps to maintain contacts & {$[105]$} \\
6 & Reduces the cost of purchasing books & {$[106]$} \\
7 & Improves confidence & {$[107]$} \\
8 & Improves social and communications skills & {$[108]$} \\
9 & Increases knowledge & {$[109,110]$} \\
\hline Sr. \# & Reduces stress & {$[45]$} \\
\hline & Influencing Factors & References Source \\
\hline 1 & Negative Factors & \\
2 & Lack of critical thinking & {$[111,112]$} \\
3 & Waste of time & {$[17]$} \\
4 & Leads to breakups on study connectivity & {$[113]$} \\
5 & Increases cyber-bullying & {$[16]$} \\
6 & Creates laziness in Students' & {$[116,117]$} \\
7 & Creates depression, anxiety & {$[60,63,118]$} \\
8 & Problematic communications & {$[63,119]$} \\
9 & Health hazards in a student's life & {$[120,121]$} \\
\hline
\end{tabular}

\subsection{Questionnaire Design}

The questionnaire design for this proposed study was prepared in two portions to examine the opinions of the respondents. The preliminary survey portion collected demographic information about the respondents, such as age, education gender, and residential regions. The second part of the survey consisted of 18 inquiries selected from the literature on the impact of social media. This study also included an open-ended question to gather information about the perception of students' learning behavior through social media. The survey asked university students to answer questions based on positive and negative factors, indicating how such elements affected their daily lives, especially with respect to sustainable educational learning. The survey was based on a five-point Likert scale to assess the degree of agreement.

\subsection{Sample Size and Population}

The sample size of this study consisted of 1013 bachelor's and master's degree students in the age range of 16-35 years from the selected universities located in five regions of Pakistan. This study utilized a mixed method sampling technique, and the respondents from all five selected areas participated. We distributed 1013 questionnaires among the targeted sample of university students and collected 831 complete/valid responses. A consent form and an invitation letter was distributed among the respondents. We explained the procedure and objective to the participants and assured that the data received is confidential. During the administration of the survey, we provided the respondents an adequate amount of time of 14 days to complete the survey and return the filled forms. Data were received from diverse geographical areas, including Gilgit, Khyber Pakhtunkhwa (KPK), Sindh, Punjab, and Baluchistan to create a representative sample of the whole country. The sample of demographic representatives is displayed in the Table 3 below. 
Table 3. Demographic profile of study participants.

\begin{tabular}{cccccccc}
\hline & \multicolumn{7}{c}{ Characteristics of Demographics } \\
\hline Regions & Male & Female & $\mathbf{1 6 - 2 0}$ & $\mathbf{2 1 - 2 5}$ & $\mathbf{2 6 - 3 0}$ & $\mathbf{3 1 - 3 5}$ & Total \\
\hline Gilgit-Baltistan & 55 & 100 & 44 & 65 & 35 & 11 & 155 \\
KPK Prov. & 60 & 150 & 80 & 50 & 75 & 5 & 160 \\
Punjab Prov. & 80 & 170 & 70 & 90 & 50 & 40 & 250 \\
Sindh Prov. & 100 & 80 & 80 & 50 & 40 & 10 & 180 \\
Baluchistan & 24 & 12 & 15 & 10 & 10 & 1 & 36 \\
Total & 319 & 512 & 289 & 265 & 210 & 67 & 831 \\
\hline
\end{tabular}

Note: Prov. = Province.

\subsection{Feedback of Questionnaire and Data Processing}

After the administration of the survey, we collected the questionnaires from the respondents, and the data received were verified, confirmed, and entered into the SPSS software version 25. Next, descriptive statistics, frequency analysis, reliability, descriptive statistics analysis, ANOVA, and a $t$-test were performed on the valid data of the 831 respondents. The response rate was calculated to be $82.033 \%$, which is an excellent response rate. Our findings show that $53.08 \%$ of the respondents hold a master's degree; $26.02 \%$ of the respondents hold a bachelor's degree, and $20.90 \%$ of the student respondents hold a professional degree.

Table 4 presents nine selected social media factors. The value of Cronbach's alpha for the positive social media factors measured was satisfactory $(\alpha=0.762)$, and the negative social media factors also presented a satisfactory Cronbach's alpha value $(\alpha=0.815)$. Data consistency reflects the data source, and it requires information about the respondents' understanding of the selected questionnaire. This study applied Cronbach's alpha $(\alpha)$ to assess the reliability of the received data, and the calculating instrument was SPSS version 25. Therefore, the reliability of the survey questionnaire revealed an acceptable value of Cronbach's alpha $(\alpha=0.762, \alpha=0.815)$ for both the positive and negative social media factors, and these results show that the respondents had a full grip and understanding of the information included in the survey and good familiarity with the impact of the positive and negative elements of social media use on the student community.

Table 4. Reliability test-positive and negative factors.

\begin{tabular}{cc}
\hline \multicolumn{2}{c}{ Reliability Test-Positive Factors } \\
\hline Scale Items & Data Reliability \\
\hline No. of items $=9$ & Cronbach's Alpha \\
Positive factors of social media & 0.762 \\
\hline Reliability Test-Negative Factors \\
\hline Scale Items & Data Reliability \\
\hline No. of items $=9$ & Cronbach's Alpha \\
Negative factors of social media & 0.815 \\
\hline Note: Cronbach's alpha values for positive and negative factors.
\end{tabular}

\section{Results}

\subsection{Perceptions of the Impact of Social Media on the Sustainable Development of Education.}

We interviewed $42 \mathrm{Ph}$.D. students with computer science backgrounds from various universities to get their fair and expert opinions regarding the impact of social media on the learning behavior of university students with respect to the issue of sustainable educational development. This section presents the findings of these expert interviews on the impact of social media. Almost $65 \%$ of the technology experts stated that social media plays an indispensable role in the learning process of university students in Pakistan, while 35\% of experts noted that although they favor the use of social 
media, they believe that students do not perform well in the learning process as a result of using social media. These results provide a clear indication of the significance of social media on learning behavior in select Pakistani universities.

\subsection{Data Analysis}

With respect to data analysis, the primary challenge of this specific study was to explore and determine the most influential social media factors and their ultimate impact on the students' communities. These factors were identified from the previous literature after an in-depth investigation, and each element was analyzed independently. Table 5 displays the mean score (M) and standard deviation (SD) of the selected positive social media factors.

Table 5. Participants using various applications of social media.

\begin{tabular}{ccccc}
\hline Social Media Types & Frequency & Percent & Valid Percent & Cumulative Percent (\%) \\
\hline Facebook and What's App & 341 & 41.0 & 41.0 & 41.0 \\
Skype and Twitter & 96 & 11.6 & 11.6 & 52.6 \\
Webchat and Snape Chat & 65 & 7.8 & 7.8 & 60.4 \\
YouTube & 263 & 31.6 & 31.6 & 92.1 \\
All & 66 & 7.9 & 7.9 & 100.0 \\
Total & 831 & 100.0 & 100.0 & \\
\hline
\end{tabular}

\subsection{Overall Ranking: Positive Factors of Social Media}

Table 6 demonstrates the mean scores (M) and standard deviations (SD) of selected positive social media factors. The results of all the positively related factors are close to each other. The most significant impacts of social media include the following: Creates awareness $(M=4.0241, S D=1.3566)$, Easy communication ( $\mathrm{M}=4.0144, \mathrm{SD}=1.3298)$, Helpful to maintain contacts $(\mathrm{M}=4.0903, \mathrm{SD}=1.1955)$, Reduces purchasing cost of books $(\mathrm{M}=4.0542, \mathrm{SD}=1.3101)$, Improving the individuals social and communication skills $(\mathrm{M}=4.0830, \mathrm{SD}=1.3431)$, and Reduces stress $(\mathrm{M}=4.0457, \mathrm{SD}=1.3282)$.

Table 6. Mean scores $(\mathrm{M})$, and std. deviation $(\mathrm{N}=831)$ of positive factors of social media.

\begin{tabular}{cccc}
\hline Sr. No. & Positive Factors of Social Media Use & M & SD \\
\hline 1 & Creates awareness & 4.0241 & 1.3566 \\
2 & Lecture sharing & 2.7413 & 1.2308 \\
3 & Easy communication & 4.0144 & 1.3298 \\
4 & Helps to maintain contacts & 4.0903 & 1.1955 \\
5 & Reduces the cost of purchasing books & 4.0542 & 1.3101 \\
6 & Improves confidence & 3.3466 & 1.1281 \\
7 & Improves social and communication skills & 4.0830 & 1.3431 \\
8 & Increases knowledge & 2.6558 & 1.3197 \\
9 & Reduces stress & 4.0457 & 1.3282 \\
\hline
\end{tabular}

Note: Mean scores and standard deviations of positive factors.

\subsection{Overall Ranking: Negative Factors of Social Media}

Table 7 displays the adverse or harmful impacts of the excessive use of social media and nine critical factors selected from the literature. Table 6 shows the most impactful negative factors, the respective mean score (M) and standard deviation (SD), and the positioning of the elements of this group based on the respondents' views: Lack of critical thinking $(\mathrm{M}=4.0975, \mathrm{SD}=1.3076)$, Waste of time $(\mathrm{M}=2.2058, \mathrm{SD}=1.0664)$, Disrupted writing skills $(\mathrm{M}=4.0241, \mathrm{SD}=1.3566)$, Leads to breakups in study connectivity $(\mathrm{M}=4.0878, \mathrm{SD}=1.3374)$, Creates laziness in students $(\mathrm{M}=4.0866$, $\mathrm{SD}=1.3207)$, and Health hazards $(\mathrm{M}=4.0710, \mathrm{SD}=1.3285)$. The mean scores of the selected factors are shown respectively. 
Table 7. Mean scores $(\mathrm{M})$, and std. deviation $(\mathrm{N}=831)$ of negative factors of social media.

\begin{tabular}{cccc}
\hline Sr. No. & Negative Factors of Social Media Use & M & SD \\
\hline 1 & Lack of critical thinking & 4.0975 & 1.3076 \\
2 & Waste of time & 2.2058 & 1.0664 \\
3 & Disrupted writing skills & 4.0241 & 1.3566 \\
4 & Leads to breakups study connectivity & 4.0878 & 1.3374 \\
5 & Increases cyber-bullying & 2.2022 & 1.0425 \\
6 & Creates laziness in Students' & 4.0866 & 1.3207 \\
7 & Creates depression, anxiety & 2.6679 & 1.2459 \\
8 & Problematic communications & 2.6943 & 1.1608 \\
9 & Health hazards in a student's life & 4.0710 & 1.3285 \\
\hline
\end{tabular}

Note: Mean scores and standard deviations of negative factors.

\subsection{The T-test}

We conducted a t-test to examine whether there was a significant difference between the mean scores of two independent groups of respondents [122]. The t-test is the most frequently applied method in a case with a normal distribution of known test statistics. A t-test is a specific statistical tool that is used to determine and test the significance of two different sets of data. The significance value of the $t$-test is set at 0.05 , and the results assess the gap between two independent factors expressing the importance of specific elements. There is no significant difference between the two factors (standalone/independent) if the resulting value is higher than a typical value of 0.05 , and the two groups would not be considered consistent in their perceptions [123]. As awareness and current involvement between the two groups of social media users existed in the students' communities, the $t$-test was applied to determine whether the importance of individual factors affected the respondents of group 1 and group 2 with respect to their difference of opinions. The results of the $t$-test, mean scores (M), standard deviation (SD), and the significance value of each selected variable are displayed in Table 8.

Table 8. Positive factors of social media use, mean scores, SD, code-significance, significance and (Y/N).

\begin{tabular}{|c|c|c|c|c|c|c|c|}
\hline \multirow[t]{2}{*}{ Sr. No. } & \multicolumn{3}{|c|}{ Category 1 (Males) } & \multicolumn{2}{|c|}{ Category 2 (Females) } & \multirow[b]{2}{*}{$\begin{array}{l}\text { Sign. } \\
\text { Diff. }\end{array}$} & \multirow[b]{2}{*}{$(\mathrm{Y} / \mathrm{N})$} \\
\hline & $\begin{array}{c}\text { Positive } \\
\text { Factors }\end{array}$ & Mean & SD & Mean & SD & & \\
\hline 1 & PMF1 & 3.8314 & 1.4577 & 4.0858 & 1.3077 & 0.005 & $\mathrm{Y}$ \\
\hline 2 & PMF2 & 2.8627 & 1.3165 & 2.6348 & 1.1694 & 0.000 & $\mathrm{Y}$ \\
\hline 3 & PMF3 & 3.7569 & 1.4539 & 4.0858 & 1.3077 & 0.003 & $\mathrm{Y}$ \\
\hline 4 & PMF4 & 4.2902 & 1.1092 & 3.9632 & 1.2347 & 0.140 & $\mathrm{~N}$ \\
\hline 5 & PMF5 & 3.9294 & 1.3232 & 4.0858 & 1.3077 & 0.611 & $\mathrm{~N}$ \\
\hline 6 & PMF6 & 3.4039 & 1.1353 & 3.3039 & 1.1328 & 0.721 & $\mathrm{~N}$ \\
\hline 7 & PM F7 & 3.9216 & 1.4614 & 4.0858 & 1.3077 & 0.100 & $\mathrm{~N}$ \\
\hline 8 & PMF8 & 3.0118 & 1.4808 & 2.3922 & 1.1230 & 0.000 & $\mathrm{Y}$ \\
\hline 9 & PMF9 & 3.9020 & 1.3783 & 4.0858 & 1.3077 & 0.244 & $\mathrm{~N}$ \\
\hline
\end{tabular}

Note: Results showed that both categories respondents admitted that positive and negative factors of social media influence their social behavior.

Table 9 displays the findings that the second group of respondents showed a higher level of interest in the importance of all the vital factors of social media use as compared with the group 1 respondents. The respondents of group 1 and group 2 believed that the use of social media and web-based social networking have a positive and negative influence on students' behavior, and to some extent, influence the social behavior of students. 
Table 9. Shows negative factors of social media use, Mean scores, SD, code-significance, significance and $(\mathrm{Y} / \mathrm{N})$.

\begin{tabular}{|c|c|c|c|c|c|c|c|}
\hline \multirow[t]{2}{*}{ Sr. No. } & \multicolumn{3}{|c|}{ Category 1 (Males) } & \multicolumn{2}{|c|}{ Category 2 (Females) } & \multirow[b]{2}{*}{ Sign. Diff. } & \multirow[b]{2}{*}{$(\mathrm{Y} / \mathrm{N})$} \\
\hline & Negative Factors & Mean & SD & Mean & SD & & \\
\hline 1 & NMF1 & 4.0627 & 1.32955 & 4.0858 & 1.3077 & 0.602 & $\mathrm{~N}$ \\
\hline 2 & NMF2 & 2.1137 & 0.99150 & 2.1495 & 1.0109 & 0.565 & $\mathrm{~N}$ \\
\hline 3 & NMF3 & 3.8314 & 1.45774 & 4.0858 & 1.3077 & 0.005 & $\mathrm{Y}$ \\
\hline 4 & NMF4 & 4.0078 & 1.42804 & 4.0858 & 1.3077 & 0.093 & $\mathrm{Y}$ \\
\hline 5 & NMF5 & 2.2941 & 1.09210 & 2.1495 & 1.0109 & 0.048 & $\mathrm{Y}$ \\
\hline 6 & NMF6 & 4.0353 & 1.36417 & 4.0858 & 1.3077 & 0.574 & $\mathrm{~N}$ \\
\hline 7 & NMF7 & 3.3490 & 1.10464 & 2.1936 & 1.0512 & 0.246 & $\mathrm{~N}$ \\
\hline 8 & NMF8 & 3.9843 & 1.38601 & 4.0858 & 1.3077 & 0.230 & $\mathrm{~N}$ \\
\hline 9 & NMF9 & 2.6314 & 1.10002 & 4.0858 & 1.3077 & 0.144 & $\mathrm{~N}$ \\
\hline
\end{tabular}

Note: Results showed that category 2, female respondents showed a higher tendency and declared extra importance to the significance of influencing elements of social media as compared to the respondents of category 1. Conclusively, both categories' respondents admitted that the positive and negative factors of social media affect their social behavior and lifestyle.

\subsection{One-Way Analysis of Variance (ANOVA)}

Tables 10-12 show one-way ANOVA analysis of the positive and negative social media factors based on the responses of students from select Pakistani universities.

Table 10. Shows positive factors among groups 1, 2 and 3 with mean (M) F value, and sig. diff. codes.

\begin{tabular}{cccccccc}
\hline Sr. No. & Positive Factors & Group 1 (Mean) & Group 2 (Mean) & Group 3 (Mean) & F & Sign. Diff. & (Y/N) \\
\hline 1 & PMF1 & 3.8119 & 4.1432 & 3.9819 & 4.506 & 0.011 & Y \\
2 & PMF2 & 2.9450 & 2.6600 & 2.6928 & 4.120 & 0.017 & Y \\
3 & PMF3 & 3.7431 & 4.1432 & 4.0241 & 6.728 & 0.001 & Y \\
4 & PMF4 & 4.3716 & 3.9575 & 4.1205 & 8.969 & 0.000 & Y \\
5 & PMF5 & 3.8211 & 4.1432 & 3.3313 & 4.736 & 0.009 & $\mathrm{Y}$ \\
6 & PMF6 & 3.3670 & 3.3423 & 4.0120 & 0.054 & 0.948 & $\mathrm{~N}$ \\
7 & PMF7 & 4.0138 & 4.1432 & 2.7952 & 0.970 & 0.380 & $\mathrm{~N}$ \\
8 & PMF5 & 3.0550 & 2.4094 & 4.0361 & 19.527 & 0.000 & $\mathrm{Y}$ \\
9 & PMF9 & 3.8532 & 4.1432 & 4.0120 & 3.519 & 0.030 & $\mathrm{Y}$ \\
\hline
\end{tabular}

Note: Table shows positive factors of social media use, among group 1, 2 and 3 with mean scores, F value, and sig. codes.

Table 11. Shows positive factors of SM among group 1, 2 \& 3 with mean scores, F value, and significant difference code.

\begin{tabular}{|c|c|c|c|c|c|c|c|}
\hline Sr. No. & Positive Factors & Group 1 (Mean) & Group 2 (Mean) & Group 3 (Mean) & $\mathbf{F}$ & Sign. Diff. & $(\mathrm{Y} / \mathrm{N})$ \\
\hline 1 & PMF1 & 3.8119 & 4.1432 & 3.9819 & 4.506 & 0.011 & $\mathrm{Y}$ \\
\hline 2 & PMF2 & 2.9450 & 2.6600 & 2.6928 & 4.120 & 0.017 & $\mathrm{Y}$ \\
\hline 3 & PMF3 & 3.7431 & 4.1432 & 4.0241 & 6.728 & 0.001 & $\mathrm{Y}$ \\
\hline 4 & PMF4 & 4.3716 & 3.9575 & 4.1205 & 8.969 & 0.000 & $\mathrm{Y}$ \\
\hline 5 & PMF5 & 3.8211 & 4.1432 & 3.3313 & 4.736 & 0.009 & $\mathrm{Y}$ \\
\hline 6 & PMF6 & 3.3670 & 3.3423 & 4.0120 & 0.054 & 0.948 & $\mathrm{~N}$ \\
\hline 7 & PMF7 & 4.0138 & 4.1432 & 2.7952 & 0.970 & 0.380 & $\mathrm{~N}$ \\
\hline 8 & PMF8 & 3.0550 & 2.4094 & 4.0361 & 19.527 & 0.000 & $\mathrm{Y}$ \\
\hline 9 & PMF9 & 3.8532 & 4.1432 & 4.0120 & 3.519 & 0.030 & $\mathrm{Y}$ \\
\hline
\end{tabular}

Note: The positive factors of social media use, among groups 1, 2 and 3 with mean scores, $F$ value, and sig. codes.

This study has tested one one-way analysis of variance, called one-way ANOVA to examine the significant difference of viewpoints among three selected groups and this technique is applied to compare the mean scores of these three groups [122]. Correspondingly, the ANOVA method is used to measure whether respondents' viewpoints are consistent with each selected study variables. There was a high degree of disagreement among the groups if the significant amount is less than 0.05 . In contrast, if the considerable value is higher than 0.05 , there is no disagreement between the two 
groups [124]. The significant values are calculated by applying the statistical tool SPSS version 25, and the results are shown in the table below.

Table 12. Social media negative factors among groups 1, 2 and 3 with mean scores, F value, and sig. diff. Code.

\begin{tabular}{cccccccc}
\hline Sr. No. & Negative Factors & Group 1 (Mean) & Group 2 (Mean) & Group 3 (Mean) & F & Sign. Diff. & (Y/N) \\
\hline 1 & NMF1 & 4.0688 & 4.1432 & 2.1867 & 0.679 & 0.507 & $\mathrm{Y}$ \\
2 & NMF2 & 2.3394 & 2.1477 & 3.9819 & 2.411 & 0.090 & $\mathrm{~N}$ \\
3 & NMF3 & 3.8119 & 4.1432 & 3.9819 & 4.506 & 0.011 & $\mathrm{Y}$ \\
4 & NMF4 & 4.0550 & 4.1432 & 2.1145 & 0.969 & 0.380 & $\mathrm{~N}$ \\
5 & NMF5 & 2.3807 & 2.1477 & 4.2952 & 4.433 & 0.012 & $\mathrm{Y}$ \\
6 & NMF6 & 3.8119 & 4.1432 & 2.8133 & 7.304 & 0.001 & $\mathrm{Y}$ \\
7 & NMF7 & 3.1972 & 2.3557 & 4.0663 & 37.942 & 0.000 & $\mathrm{Y}$ \\
8 & NMF8 & 3.9266 & 4.1432 & 2.7410 & 1.953 & 0.143 & $\mathrm{Y}$ \\
9 & NMF9 & 2.7294 & 2.6600 & 3.9819 & 0.429 & 0.652 & $\mathrm{~N}$ \\
\hline
\end{tabular}

Note: Group 1 = Bachelor degree, Group 2 = Master degree, Group 3 = Professional \& Distance learning students with age range 16 to 35 years.

We used one-way ANOVA to examine the significant difference of viewpoints among three selected groups, and this technique was applied to compare the mean scores of these three groups [122]. Correspondingly, the ANOVA method was used to measure whether the respondents' viewpoints are consistent with each selected study variables. If the significant amount is less than 0.05 , then the results show a high degree of disagreement among the groups. In contrast, if the considerable value is higher than 0.05 , there is no disagreement between the two groups [124]. The significant values were calculated by applying the statistical tool SPSS version 25 , and the results are shown below.

\section{Discussion}

This research presents new empirical findings regarding social media usage, and it aimed to examine the effects of social media on university students' learning behavior and social change [32]. The aim of this study is supported by the prior literature, as social media has become a vital element of education, and it has become increasingly important in both course delivery and course assessments. The work of Stathopoulou et al. (2019) revealed that incorporating social media in education has a positive impact on students' deep learning experience. Social media is a supporting tool for students during the learning process, and it is helpful for educators as well. However, teachers and parents have been advised to maintain a healthy balance when allowing the use of social media, as excessive use may result in adverse effects on students [33]. These study findings revealed that social media has both positive and negative impacts on students' learning processes, and a balanced approach is recommended while using social media applications [3,125]. The results of the study by Balakrishnan and Gan (2016) showed that student enrollment positively impacts learning performance, and learning motivation positively influences students [126]. Another study revealed that emerging social media applications encourage students to use social media for learning based on students' different learning styles [51]. Scholars have examined social media to determine its potential use for practitioners of technical communication [127], while social media has broader effects for students in classrooms [128]. In her research article about building a case study on technology, Bernadette Longo stated that social media is an integral part of the large and complex social networks that make up human technologies [129]. In social media, influential people are typically those exerting strong influences on peers to change their behavior, attitudes, and interaction [130,131]. Social computing facilitates social influencing behavioral research, and it is concerned with social behavior [132]. The analysis of a social network is a popular technique to assess social media users' social influence identification [133-135].

Previous study evidence revealed that social media use has a relationship with mental health in young students. Female students showed more symptoms of depression than males [55]. Excessive social media use may cause depression, stress, and anxiety among students $[60,63]$ and may increase cyber-bullying [16], the wasting of time [17], and health hazards in a student's life [120,121]. 
According to a 2015 survey on social media influences on students' social behavior in the USA, $60 \%$ of youths use social media $2 \mathrm{~h}$ per day. Ultimately, excessive social media use is linearly linked with real-life social isolation, and it impacts social behavior negatively [136]. By February 2017, Snapchat use had reached 79\% engagement among the younger generations [137,138]. In Hong Kong, almost $96 \%$ of people using smartphones browse the internet daily, which is the highest percentage in Asian countries [120]. In the proceedings of the 10th International Conference SCSM 2018, it was concluded that social media users experience a change in social behavior by using social media excessively, raising privacy, motivation, isolation and ethical issues [139].

Here, the strengths of this study include the large and diversified sample of Pakistani adult students from selected universities, the social media survey, and the validated depression, anxiety, and stress measures overlapping with the symptoms of such health issues [29,30]. Prospective research studies are suggested to determine whether the excessive use of social media creates a causal risk of stress, anxiety depression, and other health symptoms and whether the negative aspects of social media are related to health impairment [60]. Regarding the positive contribution of social media, social media applications in the medical field, educational institutions, service organizations, fashion industry, tourism, and social interactions are helpful [140]. The technical contributions of social media are vast. An earlier study examined the structure of socio-technical systems, and the influence of particular social and technological features of social media on users' inclination to donate to content creators via social media campaigns. The technical contribution of social media show that it is an important platform of socio-technical information [141]. The findings of a study on "massive open online courses" (MOOCs) demonstrated the improved performance of students when they participate in the learning process through social media platforms. It also showed that the involvement of social media and technology in learning programs is helpful in reducing the drop-out rates of students. Online courses are growing, and students are increasingly opting to take such courses. From 1998-2008, student enrollment in online education increased by $150 \%$ in the USA, and MOOCs, similar to Coursera, have served nearly 1.3 million students in India. Almost 70\% of Indian students use smartphones, forming a massive target group of the MOOC study [142]. In her preliminary results on learning outcomes via social media and technology effectiveness, Maria Joseph Israel (2015) discussed the effect of social media on students and teachers in the blended MOOC format [143].

\section{Conclusions}

This research focused to investigate the positive and adverse effects of social media on students' learning environment. In the current era, the traditional teaching "models" and learning environment receive heavy criticism because of their inability to provide students room for variation [144,145], and the incredibly increasing popularity of social media has made the transition to supplementary flexible models of teaching a necessity [145]. This work contributes to the pertinent literature by investigating social media use based on the data of this population. This study argues that it is a novel contribution to scientific knowledge as there was no prior existing literature evidence that bridges and integrates the students' views on the adoption of social media as a supporting tool in higher education. Students and educators are recognized as the most pertinent stakeholders from an educational point of view as these two-use social medial applications to facilitate learning environment and co-creation of knowledge [146].

The positive aspects of social media include its technical contribution to educational institutions and several industries, such as health, services, tourism, and communities. The positive characteristics include the sharing of opinions with others; the raising of awareness; the sharing of knowledge; the building of relationships, identity, reputation, and contacts; the improving of social influence; and the development of other communication skills. Social media is increasing across the world, and an increasing number of adolescents, student communities, and others are joining these social media sites to interact with friends, family, and strangers. Social media influences human behavior, and technological advancements have contributed technically to improve learning and 
social interactions, information sharing, and the receipt of updates through social networks. Social media applications are beneficial in educational institutions, medical sciences, and business firms. Social media has significantly transformed over the last decade the ways in which people, social communities, and other organizations create, share, and consume information. The emergence of social media has shaped the world in many ways, and it has been affecting people of all walks of life.

The adverse factors of social media, such as depression, stress, anxiety, and other health problems, explored in this study influence the student communities of Pakistan. Students of selected universities preferred to utilize social media for creating awareness, reducing stress, gaining useful information, and making new friends. In contrast, some students spend excessive time on social media, resulting in great amounts of wasted time [17]. One dangerous result of the reliance on online technology is that some fraudulent institutes have provided a bogus degree through online learning, and students fall into their trap. Moreover, some students use online jargon while completing homework and writing exams and papers, suggesting that social media and social networks have blurred the difference between formal and informal writing [31]. The excessive use of social media makes students emotionally and physically imbalanced and results in dull or irritable behavior. Considering the pros and cons of social media, students' parents should impose regulations on their children's use of social media, as the negative impact of social media may affect a student's educational performance [32]. These findings are useful to encourage parents to keep an eye on their children, because excessive use of social media is harmful to adolescents. This balanced approach is useful, because using social media during the learning process provides benefits to students. However, the adverse effects of social media might cause health damage with disproportionate use [33]. Typically, students prefer to communicate with classmates and friends in person. Students may experience fraud or scams during the use of social media, as social sites are used from time to time to take advantage of other users. Social media has drastically and negatively influenced students by setting unrealistic expectations and causing stressful situations. Such adverse impacts may cause health issues with excessive social media use, such as anxiety, stress and depression disorders, brainwashing, the absorption of fake news, marriages breakups, trolling, cyberbullying, privacy abuses, online witch hunts, and the wasting of time [17,147].

In this study, a conceptual model was experimentally tested by surveying real users of social media after a comprehensive review of technology acceptance, technology addiction, and meetings with student communities at select universities. The findings reveal that technology acceptance, its ease of use, and its perceived benefits play a decisive role in students' decisions to use social media. These findings suggest that taking a balanced approach to social media can help avoid the negative health consequences of excessive social media use. Government officials can also benefit from these findings, and they can take appropriate measures to protect the health of students and others in society from the excessive use of social media. In short, student communities described their observations of online posts or content that encouraged them to develop behaviors to prevent adverse emotional responses. Future research should investigate additional factors to expand on the elements already used in this study to gain additional insight into students' attitudes towards the sustainable consumption of social media. Further investigations should also explore the effects of specific social networking platforms, including Facebook, WeChat, What's App, and Twitter. Moreover, similar studies can be conducted by including other age groups besides university students or by examining other cities in Pakistan.

Author Contributions: J.A. (Jaffar Abbas) has conceptualized the idea, completed Literature, Introduction, Discussion Conclusion and edited the original manuscript, J.A. (Jaffar Aman) has drafted methodology and analysis section, S.B. collected data and helped resource. M.N. has reviewed the edited manuscript and provided resource.

Funding: The authors are thankful to Shanghai Jiao Tong University (SJTU) for approving the research funding from his research budget of the financing for conducting research, the rigorous process of data collection, and other associated costs for this study. 
Acknowledgments: Special thanks to MDPI professional language editing services to ensure that English grammar is free of mistakes for this manuscript. Jinzu Ling and Prof. Li Ben-qian supervised the project. The authors also acknowledge the support from BSE Lab, Prince Sultan University.

Conflicts of Interest: The authors are well informed about the study's objectives and provided consent and have declared that they have no competing interest.

\section{References}

1. Raghavendra, P.; Hutchinson, C.; Grace, E.; Wood, D.; Newman, L. "I like talking to people on the computer": Outcomes of a home-based intervention to develop social media skills in youth with disabilities living in rural communities. Res. Dev. Disabil. 2018, 76, 110-123. [CrossRef] [PubMed]

2. Sapountzi, A.; Psannis, K.E. Social networking data analysis tools \& challenges. Future Gener. Comput. Syst. 2018, 86, 893-913.

3. Lee, A.R.; Suzanne Horsley, J. The role of social media on positive youth development: An analysis of 4-H Facebook page and 4-H'ers' positive development. Child. Youth Serv. Rev. 2017, 77, 127-138. [CrossRef]

4. Yusop, F.D.; Sumari, M. The Use of Social Media Technologies among Malaysian Youth. Procedia Soc. Behav. Sci. 2013, 103, 1204-1209. [CrossRef]

5. Mayhew, A.; Weigle, P. Media Engagement and Identity Formation among Minority Youth. Child Adolesc. Psychiatr. Clin. North Am. 2018, 27, 269-285. [CrossRef] [PubMed]

6. Nielsen, M.I.S.W. Computer-mediated communication and self-awareness-A selective review. Comput. Hum. Behav. 2017, 76, 554-560. [CrossRef]

7. Russell, B.S.; Maksut, J.L.; Lincoln, C.R.; Leland, A.J. Computer-mediated parenting education: Digital family service provision. Child. Youth Serv. Rev. 2016, 62, 1-8. [CrossRef]

8. Shepherd, S.V.; Freiwald, W.A. Functional Networks for Social Communication in the Macaque Monkey. Neuron 2018, 99, 413-420.e3. [CrossRef]

9. Birim, B. Evaluation of Corporate Social Responsibility and Social Media as Key Source of Strategic Communication. Procedia Soc. Behav. Sci. 2016, 235, 70-75. [CrossRef]

10. Pivec, M.; Maček, A. Employment background influence on social media usage in the field of European project management and communication. J. Bus. Res. 2019, 94, 280-289. [CrossRef]

11. Scholz, M.; Schnurbus, J.; Haupt, H.; Dorner, V.; Landherr, A.; Probst, F. Dynamic effects of user- and marketer-generated content on consumer purchase behavior: Modeling the hierarchical structure of social media websites. Decis. Support Syst. 2018, 113, 43-55. [CrossRef]

12. Zhu, L.; Anagondahalli, D.; Zhang, A. Social media and culture in crisis communication: McDonald's and KFC crises management in China. Public Relat. Rev. 2017, 43, 487-492. [CrossRef]

13. Intravia, J.; Wolff, K.T.; Paez, R.; Gibbs, B.R. Investigating the relationship between social media consumption and fear of crime: A partial analysis of mostly young adults. Comput. Hum. Behav. 2017, 77, 158-168. [CrossRef]

14. Reddick, C.G.; Norris, D.F. Social media adoption at the American grass roots: Web 2.0 or 1.5? Gov. Inf. Q. 2013, 30, 498-507. [CrossRef]

15. Yoo, J.H.; Jeong, E.J. Psychosocial effects of SNS use: A longitudinal study focused on the moderation effect of social capital. Comput. Hum. Behav. 2017, 69, 108-119. [CrossRef]

16. Carter, M.A. Protecting Oneself from Cyber Bullying on Social Media Sites-A Study of Undergraduate Students. Procedia Soc. Behav. Sci. 2013, 93, 1229-1235. [CrossRef]

17. Malita, L. Social media time management tools and tips. Procedia Comput. Sci. 2011, 3, 747-753. [CrossRef]

18. Hardy, B.W.; Castonguay, J. The moderating role of age in the relationship between social media use and mental well-being: An analysis of the 2016 General Social Survey. Comput. Hum. Behav. 2018, 85, $282-290$. [CrossRef]

19. Chen, H.-T.; Li, X. The contribution of mobile social media to social capital and psychological well-being: Examining the role of communicative use, friending and self-disclosure. Comput. Hum. Behav. 2017, 75, 958-965. [CrossRef]

20. Wu, Y.; Xie, L.; Huang, S.L.; Li, P.; Yuan, Z.; Liu, W. Using social media to strengthen public awareness of wildlife conservation. Ocean Coast. Manag. 2018, 153, 76-83. [CrossRef]

21. Strathdee, R. Social Exclusion and the Remaking of Social Networks; Taylor \& Francis: Abingdon, UK, 2017. 
22. Valenzuela, S. Unpacking the Use of Social Media for Protest Behavior: The Roles of Information, Opinion Expression, and Activism. Am. Behav. Sci. 2013, 57, 920-942. [CrossRef]

23. Buzzanell, P.M. Rethinking Organizational and Managerial Communication from Feminist Perspectives; SAGE Publications: Thousand Oaks, CA, USA, 2000.

24. Martin, J.N.; Nakayama, T.K. Intercultural Communication in Contexts; McGraw-Hill Education: New York, NY, USA, 2017.

25. Pierson, J.; Bauwens, J. Digital Broadcasting: An Introduction to New Media; Bloomsbury Publishing: London, UK, 2015.

26. Li, B.; Wang, L.; Lu, G. Price dynamics, social networks and communication. Financ. Res. Lett. 2017, 22, 197-201. [CrossRef]

27. Chukwuere, J.E.; Chukwuere, P.C. The impact of social media on social lifestyle: A case study of university female students. Gend. Behav. 2017, 15, 9966-9981.

28. Al-Sharqi, L.; Hashim, K.; Kutbi, I. Perceptions of social media impact on students' social behavior: A comparison between Arts and Science students. Int. J. Educ. Soc. Sci. 2015, 2, 122-131.

29. Wolf, D.M.; Wenskovitch, J.E., Jr.; Anton, B.B. Nurses' use of the Internet and social media: Does age, years of experience and educational level make a difference? J. Nurs. Educ. Pract. 2015, 6, 68. [CrossRef]

30. Terzi, B.; Bulut, S.; Kaya, N. Factors affecting nursing and midwifery students' attitudes toward social media. Nurse Educ. Pract. 2019, 35, 141-149. [CrossRef] [PubMed]

31. Hossain, M.A.; Jahan, N.; Fang, Y.; Hoque, S. Nexus of Electronic Word-Of-Mouth to Social Networking Sites: A Sustainable Chatter of New Digital Social Media. Sustainability 2019, 11, 759. [CrossRef]

32. Kim, T.T.; Karatepe, O.; Lee, G.; Demiral, H. Do Gender and Prior Experience Moderate the Factors Influencing Attitude toward Using Social Media for Festival Attendance? Sustainability 2018, 10, 3509. [CrossRef]

33. Stathopoulou, A.; Siamagka, N.-T.; Christodoulides, G. A multi-stakeholder view of social media as a supporting tool in higher education: An educator-student perspective. Eur. Manag. J. 2019, in press. [CrossRef]

34. Suseno, Y.; Laurell, C.; Sick, N. Assessing value creation in digital innovation ecosystems: A Social Media Analytics approach. J. Strateg. Inf. Syst. 2018, 27, 335-349. [CrossRef]

35. Tulin, M.; Pollet, T.V.; Lehmann-Willenbrock, N. Perceived group cohesion versus actual social structure: A study using social network analysis of egocentric Facebook networks. Soc. Sci. Res. 2018, 74, 161-175. [CrossRef]

36. Hansen, D.T. The Teacher and the World: A Study of Cosmopolitanism as Education; Taylor \& Francis: Abingdon, UK, 2017.

37. Bredl, K. Methods for Analyzing Social Media; Taylor \& Francis: Abingdon, UK, 2017.

38. Penni, J. The future of online social networks (OSN): A measurement analysis using social media tools and application. Telemat. Inform. 2017, 34, 498-517. [CrossRef]

39. Information Resources Management Association. Social Media and Networking: Concepts, Methodologies, Tools, and Applications: Concepts, Methodologies, Tools, and Applications; IGI Global: Hershey, PA, USA, 2015.

40. Baccarella, C.V.; Wagner, T.F.; Kietzmann, J.H.; McCarthy, I.P. Social media? It's serious! Understanding the dark side of social media. Eur. Manag. J. 2018, 36, 431-438. [CrossRef]

41. Hämeen-Anttila, K.; Pietilä, K.; Pylkkänen, L.; Pohjanoksa-Mäntylä, M. Internet as a source of medicines information (MI) among frequent internet users. Res. Soc. Adm. Pharm. 2018, 14, 758-764. [CrossRef] [PubMed]

42. Salmerón, L.; García, A.; Vidal-Abarca, E. The development of adolescents' comprehension-based Internet reading activities. Learn. Individ. Differ. 2018, 61, 31-39. [CrossRef]

43. Castellacci, F.; Tveito, V. Internet use and well-being: A survey and a theoretical framework. Res. Policy 2018, 47, 308-325. [CrossRef]

44. Ahmad, S.; Mustafa, M.; Ullah, A. Association of demographics, motives and intensity of using Social Networking Sites with the formation of bonding and bridging social capital in Pakistan. Comput. Hum. Behav. 2016, 57, 107-114. [CrossRef]

45. Rus, H.M.; Tiemensma, J. Social media as a shield: Facebook buffers acute stress. Physiol. Behav. 2018, 185, 46-54. [CrossRef] [PubMed] 
46. Richey, M.; Ravishankar, M.N. The role of frames and cultural toolkits in establishing new connections for social media innovation. Technol. Soc. Chang. 2017, in press. [CrossRef]

47. Berezan, O.; Krishen, A.S.; Agarwal, S.; Kachroo, P. The pursuit of virtual happiness: Exploring the social media experience across generations. J. Bus. Res. 2018, 89, 455-461. [CrossRef]

48. Mao, J. Social media for learning: A mixed methods study on high school students' technology affordances and perspectives. Comput. Hum. Behav. 2014, 33, 213-223. [CrossRef]

49. Huang, J.; Zhou, L. Timing of web personalization in mobile shopping: A perspective from Uses and Gratifications Theory. Comput. Hum. Behav. 2018, 88, 103-113. [CrossRef]

50. Gan, C.; Li, H. Understanding the effects of gratifications on the continuance intention to use WeChat in China: A perspective on uses and gratifications. Comput. Hum. Behav. 2018, 78, 306-315. [CrossRef]

51. Balakrishnan, V.; Gan, C.L. Students' learning styles and their effects on the use of social media technology for learning. Telemat. Inform. 2016, 33, 808-821. [CrossRef]

52. Hoffmann, C.; Bublitz, W. Pragmatics of Social Media; De Gruyter: Berlin, Germany, 2017.

53. le Roux, D.B.; Parry, D.A. In-lecture media use and academic performance: Does subject area matter? Comput. Hum. Behav. 2017, 77, 86-94. [CrossRef]

54. Tella, A. Social Media Strategies for Dynamic Library Service Development; IGI Global: Hershey, PA, USA, 2014.

55. Kelly, Y.; Zilanawala, A.; Booker, C.; Sacker, A. Social Media Use and Adolescent Mental Health: Findings from the UK Millennium Cohort Study. EClinicalMedicine 2018, 6, 59-68. [CrossRef]

56. Ceranoglu, T.A. Inattention to Problematic Media Use Habits: Interaction Between Digital Media Use and Attention-Deficit/Hyperactivity Disorder. Child Adolesc. Psychiatr. Clin. North Am. 2018, 27, 183-191. [CrossRef] [PubMed]

57. Colliander, J.; Marder, B.; Falkman, L.L.; Madestam, J.; Modig, E.; Sagfossen, S. The social media balancing act: Testing the use of a balanced self-presentation strategy for politicians using twitter. Comput. Hum. Behav. 2017, 74, 277-285. [CrossRef]

58. Bozoglan, B. Psychological, Social, and Cultural Aspects of Internet Addiction; IGI Global: Hershey, PA, USA, 2017.

59. Murthy, D.; Gross, A.J. Social media processes in disasters: Implications of emergent technology use. Soc. Sci. Res. 2017, 63, 356-370. [CrossRef]

60. Gaspar, R.; Pedro, C.; Panagiotopoulos, P.; Seibt, B. Beyond positive or negative: Qualitative sentiment analysis of social media reactions to unexpected stressful events. Comput. Hum. Behav. 2016, 56, 179-191. [CrossRef]

61. Dahl, S. Social Media Marketing: Theories and Applications; SAGE Publications: Thousand Oaks, CA, USA, 2018.

62. Issa, T.; Isaias, P.; Kommers, P. Social Networking and Education: Global Perspectives; Springer International Publishing: Cham, Switzerland, 2016.

63. Hawk, S.T.; van den Eijnden, R.J.; van Lissa, C.J.; ter Bogt, T.F. Narcissistic adolescents' attention-seeking following social rejection: Links with social media disclosure, problematic social media use, and smartphone stress. Comput. Hum. Behav. 2019, 92, 65-75. [CrossRef]

64. Radovic, A.; Gmelin, T.; Stein, B.D.; Miller, E. Depressed adolescents' positive and negative use of social media. J. Adolesc. 2017, 55, 5-15. [CrossRef]

65. Phua, J.; Jin, S.V.; Kim, J. Uses and gratifications of social networking sites for bridging and bonding social capital: A comparison of Facebook, Twitter, Instagram, and Snapchat. Comput. Hum. Behav. 2017, 72, 115-122. [CrossRef]

66. Chung, W.; Zeng, D. Dissecting emotion and user influence in social media communities: An interaction modeling approach. Inf. Manag. 2018, in press. [CrossRef]

67. Gibbons, J.A.; Horowitz, K.A.; Dunlap, S.M. The fading affect bias shows positive outcomes at the general but not the individual level of analysis in the context of social media. Conscious. Cogn. 2017, 53, 47-60. [CrossRef] [PubMed]

68. Sayira, T.; Andrews, H. Impacts of crises and communication media on place image: A case study of Chilas, Pakistan. J. Destin. Mark. Manag. 2016, 5, 351-360. [CrossRef]

69. Attrill, A. The Manipulation of Online Self-Presentation: Create, Edit, Re-Edit and Present; Palgrave Macmillan: Basingstoke, UK, 2015.

70. Rexiline Ragini, J.; Rubesh Anand, P.M.; Bhaskar, V. Mining crisis information: A strategic approach for detection of people at risk through social media analysis. Int. J. Disaster Risk Reduct. 2017, 27, 556-566. [CrossRef] 
71. Jackson, M. Utilizing attribution theory to develop new insights into tourism experiences. J. Hosp. Tour. Manag. 2019, 38, 176-183. [CrossRef]

72. Durkin, M.; McCartan, A.; Brady, M. Social Media and Interactive Communications: A Service Sector Reflective on the Challenges for Practice and Theory; Taylor \& Francis: Abingdon, UK, 2018.

73. Gu, J.; Xu, Y.C.; Xu, H.; Zhang, C.; Ling, H. Privacy concerns for mobile app download: An elaboration likelihood model perspective. Decis. Support Syst. 2017, 94, 19-28. [CrossRef]

74. Ta Van, C.; Zyngier, S. Using ERG theory as a lens to understand the sharing of academic tacit knowledge: Problems and issues in developing countries-Perspectives from Vietnam. In Knowledge Management and Competitive Advantage: Issues and Potential Solutions; IGI Global: Hershey, PA, USA, 2016; pp. 2012-2040.

75. Hollyforde, S.; Whiddett, S. The Motivation Handbook; Chartered Institute of Personnel and Development: London, UK, 2002.

76. Chiu, C.-M.; Wang, E.T.; Shih, F.J.; Fan, Y.W. Understanding Knowledge Sharing in Virtual Communities: An Integration of Expectancy Disconfirmation and Justice Theories. Online Inf. Rev. 2011, 35, 134-153. [CrossRef]

77. Fjermestad, J.; Robertson, N.C. Electronic Customer Relationship Management; Taylor \& Francis: Abingdon, UK, 2015.

78. Intezari, A.; Pauleen, D. Wisdom, Analytics and Wicked Problems: Integral Decision Making for the Data Age; Taylor \& Francis: Abingdon, UK, 2018.

79. Mazanec, J.A.; Crotts, J.C.; Gursoy, D.; Lu, L. Homogeneity versus heterogeneity of cultural values: An item-response theoretical approach applying Hofstede's cultural dimensions in a single nation. Tour. Manag. 2015, 48, 299-304. [CrossRef]

80. Heck, D.W.; Hilbig, B.E.; Moshagen, M. From information processing to decisions: Formalizing and comparing psychologically plausible choice models. Cogn. Psychol. 2017, 96, 26-40. [CrossRef] [PubMed]

81. Tedeschi, J.T. Impression Management Theory and Social Psychological Research; Elsevier Science: Amsterdam, The Netherlands, 2013.

82. McEvoy, J.; Gilbertz, S.J.; Anderson, M.B.; Ormerod, K.J.; Bergmann, N.T. Cultural theory of risk as a heuristic for understanding perceptions of oil and gas development in Eastern Montana, USA. Extr. Ind. Soc. 2017, 4, 852-859. [CrossRef] [PubMed]

83. Ngai, E.W.T.; Tao, S.S.C.; Moon, K.K.L. Social media research: Theories, constructs, and conceptual frameworks. Int. J. Inf. Manag. 2015, 35, 33-44. [CrossRef]

84. Gyamfi, A.; Williams, I. Evaluating Media Richness in Organizational Learning; IGI Global: Hershey, PA, USA, 2017.

85. Saat, R.M.; Selamat, M.H. An Examination of Consumer's Attitude towards Corporate Social Responsibility (CSR) Web Communication Using Media Richness Theory. Procedia Soc. Behav. Sci. 2014, 155, 392-397. [CrossRef]

86. Scheinbaum, A.C. Online Consumer Behavior: Theory and Research in Social Media, Advertising and E-Tail; Taylor \& Francis: Abingdon, UK, 2012.

87. Kim, M.J.; Lee, C.-K.; Contractor, N.S. Seniors' usage of mobile social network sites: Applying theories of innovation diffusion and uses and gratifications. Comput. Hum. Behav. 2019, 90, 60-73. [CrossRef]

88. Porter, C.E.; Donthu, N. Cultivating Trust and Harvesting Value in Virtual Communities. Manag. Sci. 2008, 54, 113-128. [CrossRef]

89. Galkina, T.; Lundgren-Henriksson, E.-L. Coopetition as an entrepreneurial process: Interplay of causation and effectuation. Ind. Mark. Manag. 2017, 67, 158-173. [CrossRef]

90. Koch, T.; Windsperger, J. Seeing through the network: Competitive advantage in the digital economy. J. Organ. Des. 2017, 6, 6. [CrossRef]

91. Calvo-Porral, C.; Ruiz-Vega, A.; Lévy-Mangin, J.-P. Does product involvement influence how emotions drive satisfaction?: An approach through the Theory of Hedonic Asymmetry. Eur. Res. Manag. Bus. Econ. 2018, 24, 130-136. [CrossRef]

92. Aigbe, S.A. Theory of Social Involvement: A Case Study in the Anthropology of Religion, State, and Society; University Press of America: Lanham, MA, USA, 2015.

93. Lovett, F. Rawls's 'A Theory of Justice': A Reader's Guide; Bloomsbury Publishing: London, UK, 2010.

94. Jasso, G.; Shelly, R.; Webster, M. How impartial are the observers of justice theory? Soc. Sci. Res. 2018, 79, 226-246. [CrossRef] [PubMed]

95. Kang, S.K.; Lee, J. Support of marijuana tourism in Colorado: A residents' perspective using social exchange theory. J. Destin. Mark. Manag. 2018, 9, 310-319. [CrossRef] 
96. Genç, V.; Onver, M.S. Issues in Tourism, Human Rights \& Sustainable Environment; IJOPEC Publication Limited: London, UK, 2018.

97. Ifinedo, P. Applying uses and gratifications theory and social influence processes to understand students' pervasive adoption of social networking sites: Perspectives from the Americas. Int. J. Inf. Manag. 2016, 36, 192-206. [CrossRef]

98. Friedkin, N.E. A Structural Theory of Social Influence; Cambridge University Press: Cambridge, UK, 2006.

99. Kadushin, C. Understanding Social Networks: Theories, Concepts, and Findings; Oxford University Press: Oxford, UK, 2012.

100. Huang, H.-C.; Cheng, T.C.; Huang, W.F.; Teng, C.I. Who are likely to build strong online social networks? The perspectives of relational cohesion theory and personality theory. Comput. Hum. Behav. 2018, 82, 111-123. [CrossRef]

101. Jackson, S.L. Research Methods and Statistics: A Critical Thinking Approach; Cengage Learning: Boston, MA, USA, 2012.

102. Adolfsson, A.; Ackerman, M.; Brownstein, N.C. To cluster, or not to cluster: An analysis of clusterability methods. Pattern Recognit. 2019, 88, 13-26. [CrossRef]

103. Royall, J.; Isyagi, M.M.; Iliyasu, Y.; Lukande, R.; Vuhahula, E. From Access to Collaboration: Four African Pathologists Profile Their Use of the Internet and Social Media. Clin. Lab. Med. 2017, 10, 5.

104. Cheng, X.; Fu, S.; de Vreede, G.-J. Understanding trust influencing factors in social media communication: A qualitative study. Int. J. Inf. Manag. 2017, 37, 25-35. [CrossRef]

105. McLean, K.; Edwards, S.; Morris, H. Community playgroup social media and parental learning about young children's play. Comput. Educ. 2017, 115, 201-210. [CrossRef]

106. Kim, N.; Kim, W. Do your social media lead you to make social deal purchases? Consumer-generated social referrals for sales via social commerce. Int. J. Inf. Manag. 2018, 39, 38-48. [CrossRef]

107. Turel, O.; Brevers, D.; Bechara, A. Time distortion when users at-risk for social media addiction engage in non-social media tasks. J. Psychiatr. Res. 2018, 97, 84-88. [CrossRef] [PubMed]

108. Charoensukmongkol, P.; Sasatanun, P. Social media use for CRM and business performance satisfaction: The moderating roles of social skills and social media sales intensity. Asia Pac. Manag. Rev. 2017, 22, 25-34. [CrossRef]

109. Leonardi, P.M. The social media revolution: Sharing and learning in the age of leaky knowledge. Inf. Organ. 2017, 27, 47-59. [CrossRef]

110. O'Connor, K.W.; Schmidt, G.B.; Drouin, M. Suspended because of social media? Students' knowledge and opinions of university social media policies and practices. Comput. Hum. Behav. 2016, 65, 619-626. [CrossRef]

111. DeWaelsche, S.A. Critical thinking, questioning and student engagement in Korean university English courses. Linguist. Education 2015, 32, 131-147. [CrossRef]

112. Sinprakob, S.; Songkram, N. A Proposed Model of Problem-based Learning on Social Media in Cooperation with Searching Technique to Enhance Critical Thinking of Undergraduate Students. Procedia Soc. Behav. Sci. 2015, 174, 2027-2030. [CrossRef]

113. Lee, C.; Shin, J.; Hong, A. Does social media use really make people politically polarized? Direct and indirect effects of social media use on political polarization in South Korea. Telemat. Inform. 2018, 35, 245-254. [CrossRef]

114. Kim, K.; Kim, J.; Reid, L.N. Experiencing motivational conflict on social media in a crisis situation: The case of the Chick-fil-A same-sex marriage controversy. Comput. Hum. Behav. 2017, 71, 32-41. [CrossRef]

115. Warren, D.M.; Bloch, K.R. Framing same-sex marriage: Media constructions of California's Proposition 8. Soc. Sci. J. 2014, 51, 503-513. [CrossRef]

116. Vangeepuram, N.; Carmona, J.; Arniella, G.; Horowitz, C.R.; Burnet, D. Use of Focus Groups to Inform a Youth Diabetes Prevention Model. J. Nutr. Educ. Behav. 2015, 47, 532-539.e1. [CrossRef] [PubMed]

117. Székely, L.; Nagy, Á. Online youth work and eYouth-A guide to the world of the digital natives. Child. Youth Serv. Rev. 2011, 33, 2186-2197. [CrossRef]

118. Abbas, J.; Aqeel, M.; Abbas, J.; Shaher, B.; Abbas, J.; Sundas, J.; Zhang, W. The moderating role of social support for marital adjustment, depression, anxiety, and stress: Evidence from Pakistani working and nonworking women. J. Affect. Disord. 2019, 244, 231-238. [CrossRef] 
119. Haslam, S.A.; McMahon, C.; Cruwys, T.; Haslam, C.; Jetten, J.; Steffens, N.K. Social cure, what social cure? The propensity to underestimate the importance of social factors for health. Soc. Sci. Med. 2018, 198, 14-21. [CrossRef] [PubMed]

120. Lee, C.K.M.; Ng, K.K.; Chan, H.K.; Choy, K.L.; Tai, W.C.; Choi, L.S. A multi-group analysis of social media engagement and loyalty constructs between full-service and low-cost carriers in Hong Kong. J. Air Transp. Manag. 2018, 73, 46-57. [CrossRef]

121. Atallah, S.; Hotle, S.L.; Mumbower, S. The evolution of low-cost Carrier operational strategies pre- and post-recession. J. Air Transp. Manag. 2018, 73, 87-94. [CrossRef]

122. Babbie, R. The Basics of Social Research; Cengage Learning: Boston, MA, USA, 2016.

123. Hedberg, E.C.; Ayers, S. The power of a paired t-test with a covariate. Soc. Sci. Res. 2015, 50, $277-291$. [CrossRef] [PubMed]

124. Smalheiser, N.R. Chapter 11-ANOVA. In Data Literacy; Smalheiser, N.R., Ed.; Academic Press: Cambridge, CA, USA, 2017; pp. 149-155.

125. van Zoonen, W.; Verhoeven, J.W.M.; Vliegenthart, R. Understanding the consequences of public social media use for work. Eur. Manag. J. 2017, 35, 595-605. [CrossRef]

126. Law, K.M.Y.; Geng, S.; Li, T. Student enrollment, motivation and learning performance in a blended learning environment: The mediating effects of social, teaching, and cognitive presence. Comput. Educ. 2019, 136, 1-12. [CrossRef]

127. Kimme Hea, A.C. Social Media in Technical Communication. Tech. Commun. Q. 2014, 23, 1-5. [CrossRef]

128. Kaufer, D.; Gunawardena, A.; Tan, A.; Cheek, A. Bringing social media to the writing classroom: Classroom salon. J. Bus. Tech. Commun. 2011, 25, 299-321. [CrossRef]

129. Longo, B. Using Social Media for Collective Knowledge-Making: Technical Communication between the Global North and South. Tech. Commun. Q. 2014, 23, 22-34. [CrossRef]

130. Nair, H.S.; Manchanda, P.; Bhatia, T. Asymmetric Social Interactions in Physician Prescription Behavior: The Role of Opinion Leaders. J. Mark. Res. 2010, 47, 883-895. [CrossRef]

131. Bruning, P.F.; Alge, B.J.; Lin, H.-C. The embedding forces of network commitment: An examination of the psychological processes linking advice centrality and susceptibility to social influence. Organ. Behav. Hum. Decis. Process. 2018, 148, 54-69.

132. Wang, J.; Aribarg, A.; Atchadé, Y.F. Modeling Choice Interdependence in a Social Network. Mark. Sci. 2013, 32, 977-997. [CrossRef]

133. Liang, Y.; Zheng, X.; Zeng, D.D.; Zhou, X.; Leischow, S.J.; Chung, W. Characterizing Social Interaction in Tobacco-Oriented Social Networks: An Empirical Analysis. Sci. Rep. 2015, 5, 10060. [CrossRef] [PubMed]

134. Hinz, O.; Skiera, B.; Barrot, C.; Becker, J.U. Seeding Strategies for Viral Marketing: An Empirical Comparison. J. Mark. 2011, 75, 55-71. [CrossRef]

135. Schlereth, C.; Barrot, C.; Skiera, B.; Takac, C. Optimal Product-Sampling Strategies in Social Networks: How Many and Whom to Target? Int. J. Electron. Commer. 2013, 18, 45-72. [CrossRef]

136. Whaite, E.O.; Shensa, A.; Sidani, J.E.; Colditz, J.B.; Primack, B.A. Social media use, personality characteristics, and social isolation among young adults in the United States. Personal. Individ. Differ. 2018, 124, 45-50. [CrossRef]

137. Medina, J. Attack of the Teenage Brain: Understanding and Supporting the Weird and Wonderful Adolescent Learner; ASCD: Alexandria, VA, USA, 2018.

138. Scheff, S.; Schorr, M.; Lewinksy, M. Shame Nation: The Global Epidemic of Online Hate; Sourcebooks: Naperville, IL, USA, 2017.

139. Meiselwitz, G. Social Computing and Social Media. User Experience and Behavior: 10th International Conference, SCSM 2018, Held as Part of HCI International 2018, Las Vegas, NV, USA, July 15-20 2018, Proceedings, Part I; Springer International Publishing: Cham, Switzerland, 2018.

140. Bail, C.A. Taming Big Data: Using App Technology to Study Organizational Behavior on Social Media. Sociol. Methods Res. 2015, 46, 189-217.

141. Wan, J.; Lu, Y.; Wang, B.; Zhao, L. How attachment influences users' willingness to donate to content creators in social media: A socio-technical systems perspective. Inf. Manag. 2017, 54, 837-850. [CrossRef]

142. Li, Y.; Zhang, M.; Bonk, C.J.; Guo, Y. Integrating MOOC and Flipped Classroom Practice in a Traditional Undergraduate Course: Students' Experience and Perceptions. Int. J. Emerg. Technol. Learn. 2015, 10, 4-10. [CrossRef] 
143. Israel, M.J. Effectiveness of integrating MOOCs in traditional classrooms for undergraduate students. Int. Rev. Res. Open Distrib. Learn. 2015, 16, 102-118. [CrossRef]

144. Haggis, T. Constructing Images of Ourselves? A Critical Investigation into 'Approaches to Learning' Research in Higher Education. Br. Educ. Res. J. 2003, 29, 89-104. [CrossRef]

145. Malcolm, J.; Zukas, M. Bridging Pedagogic Gaps: Conceptual discontinuities in higher education. Teach. High. Educ. 2001, 6, 33-42. [CrossRef]

146. Salmon, G. Computer Mediated Conferencing for Management Learning at the Open University. Manag. Learn. 2000, 31, 491-502. [CrossRef]

147. Patchin, J.W.; Hinduja, S. Cyberbullying Prevention and Response: Expert Perspectives; Taylor \& Francis: Abingdon, UK, 2012.

(C) 2019 by the authors. Licensee MDPI, Basel, Switzerland. This article is an open access article distributed under the terms and conditions of the Creative Commons Attribution (CC BY) license (http:// creativecommons.org/licenses/by/4.0/). 